\title{
OPTIMAL FERTILIZER REQUIREMENT OF RAINFED SUNFLOWER BASED ON VARYING SOIL MOISTURE STRESS INDICES ON SEMI-ARID VERTISOLS OF INDIA
}

\author{
Maruthi Sankar, G.R. ${ }^{*}$, Vittal, K.P.R. ${ }^{1}$, Pharande, A.L. ${ }^{2}$, Victor, U.S. ${ }^{1}$, \\ Ravindra Chary, G. ${ }^{1}$, Ramakrishna, Y.S. ${ }^{1}$ and Girija, A. ${ }^{1}$ \\ ${ }^{1}$ All India Coordinated Research Project for Dryland Agriculture, CRIDA, San- \\ toshnagar, Hyderabad-500 059, Andhra Pradesh, India \\ ${ }^{2}$ Cooperating Centre, AICRP for Dryland Agriculture, Mahatma Phule Krishi \\ Vidyapeeth, Solapur - 413 002, Maharastra, India
}

Received: August 17, 2006 Accepted: January 10, 2008

\section{SUMMARY}

Six field experiments were conducted on sunflower with treatments comprising of 4 dates of sowing (sown during different standard meteorological weeks viz., 28 (9-15 July), 30 (23-29 July), 32 (6-12 August) and 34 (21-26 August), 3 moisture conservation methods (ridge $\&$ furrow, skip row with furrow and flat bed) and 3 levels of fertilizer NP (40-20, 50-25 and 60-30 kg/ha) during kharif 1999 to 2004 at Solapur on semi-arid vertisols. Based on daily rainfall $(\mathrm{RF})$, daily runoff $(\mathrm{RO})$ and crop soil moisture stress index (MSI) were measured for each combination of date of sowing (DOS) and moisture conservation (MC) method in each season.

Correlation analysis indicated a positive relation of seed yield with rainfall in all 4 DOS. The relation was relatively higher for flat bed in $1^{\text {st }}$ DOS, ridge $\&$ furrow in $2^{\text {nd }}$ DOS, skip row with furrow in $3^{\text {rd }}$ and $4^{\text {th }}$ DOS. It was negatively related with RO in $1^{\text {st }}$ DOS, but positively related with the other 3 DOS. The relation was higher under ridge \& furrow system in $1^{\text {st }}$ DOS (negative) and $4^{\text {th }}$ DOS (positive), while under flat bed in $2^{\text {nd }}$ and $3^{\text {rd }}$ DOS. Negative relation of MSI was found with yield under all the 12 combinations of DOS and MC indicating a higher relation under skip row with furrow in $1^{\text {st }}, 2^{\text {nd }}$ and $4^{\text {th }}$ DOS, and flat bed in $3^{\text {rd }}$ DOS. The relation between RF and RO was positive, while MSI had negative relation with both $\mathrm{RF}$ and $\mathrm{RO}$.

Regression models of seed yield through RF, RO, SMI, fertilizer N and P, along with fertilizer $\mathrm{x}$ MSI interaction were calibrated. The predictability ranged from 0.12 (ridge and furrow in $3^{\text {rd }}$ DOS) to 0.91 (flat bed in $1^{\text {st }}$ DOS). A ready reckon of optimal $\mathrm{N}$ and $\mathrm{P}$ doses at varying $\mathrm{MSI}$ levels $(0.15$ to 0.75$)$ indicated that ridge and furrow method is efficient in $1^{\text {st }}$ DOS with an optimal $\mathrm{N}$ and $\mathrm{P}$ ranging from 51 to $53 \mathrm{~kg} / \mathrm{ha}$ and 26 to $27 \mathrm{~kg} / \mathrm{ha}$, respectively. Skip row with furrow method was efficient when crop was sown in any of the other DOS

* Corresponding author: Phone: 24530828; Fax: +91-040-24530828;

e-mail: gmsankar@crida.ernet.in 
with an optimal $\mathrm{N}$ ranging from 38 to $66 \mathrm{~kg} / \mathrm{ha}\left(2^{\text {nd }} \mathrm{DOS}\right), 44$ to $73 \mathrm{~kg} / \mathrm{ha}$ ( $3^{\text {rd }}$ DOS) and 47 to $74 \mathrm{~kg} / \mathrm{ha}$ ( $4^{\text {th }} \mathrm{DOS}$ ). The optimal P ranged from 19 to $33 \mathrm{~kg} / \mathrm{ha}$ ( $2^{\text {nd }}$ DOS), 22 to $36 \mathrm{~kg} / \mathrm{ha}$ ( $3^{\text {rd }}$ DOS) and 24 to $37 \mathrm{~kg} / \mathrm{ha}\left(4^{\text {th }} \mathrm{DOS}\right.$ ) for attaining maximum productivity of sunflower on semi-arid vertisols.

\section{Key words: soil moisture stress index, dates of sowing, moisture conserva- tion, regression models, optimization of fertilizer}

\section{INTRODUCTION}

Sunflower (Helianthus annuus) can be grown throughout the year. It is grown in both alfisols and vertisols under rainfed conditions. It is a day neutral plant and can be grown successfully in different seasons under varying conditions of day length, provided the day temperature is favorable. It grows best with clear sky and occasional rain shower during early stages. The crop requires a cool climate during germination and seedling growth and warm non-cloudy weather and high temperature from flowering to maturity. It is resistant to drought but requires continuous availability of soil moisture for optimal performance. The relation of seed yield with rainfall and other weather variables has to be assessed under rainfed conditions in order to invest in fertilizer and other inputs (Maruthi Sankar, 1992; Maruthi Sankar and Vanaja, 2003; Maruthi Sankar et al., 2004). During 2000-01, sunflower was grown on an area of 549.4 thousand ha in kharif with a production of 254.6 thousand tons, while in rabi, it was grown in an area of 785.2 thousand ha with a production of 478.4 thousand tons in the country. In kharif, the productivity was about $463 \mathrm{~kg} / \mathrm{ha}$, while in rabi it was about $609 \mathrm{~kg} / \mathrm{ha}$. It is grown in Karnataka, Maharastra, Andhra Pradesh, Tamil Nadu, Punjab, Haryana, Gujarat and other states in the country under arid, semi-arid and dry sub-humid conditions. There is a need to improve the productivity and sustainability of sunflower under rainfed conditions by improving the utilization of the received rainfall with a suitable moisture conservation practice and optimal input fertilizers (Maruthi Sankar et al., 2001; Vittal et al., 2003).

The fertilizer requirement of sunflower varies depending on the rainfall received during crop season (sowing to harvest), runoff and soil moisture stress parameters. An optimal dose based on a suitable soil water balance model would be more efficient compared with a general fertilizer dose. It is therefore required to derive crop season moisture stress index based on daily rainfall and runoff and calibrate optimal fertilizer requirement of sunflower (Doorenbos and Kassam, 1979; Victor et al., 2003). Multiple regression models of seed yield through rainfall, runoff and soil moisture stress index together with fertilizer variables could be calibrated for both prediction of seed yield and optimization of fertilizer at varying moisture stress levels (Draper and Smith, 1973; Maruthi Sankar, 1986; Hanumantha Rao et al., 1993).

An attempt is made in this paper to quantify the relations of rainfall received on different dates of sowing with the sunflower seed yield together with runoff and crop season moisture stress index based on 6 field experiments conducted in kharif season on semi-arid vertisols. Based on the regression models of seed yield involving 
rainfall, runoff, moisture stress index and fertilizer variables, an attempt is made to derive optimal $\mathrm{N}$ and $\mathrm{P}$ fertilizer requirement of sunflower for attaining maximum productivity (Maruthi Sankar, 1986; Maruthi Sankar and Sonar, 1987; Maruthi Sankar et al., 1988) and also its suitability as a contingent crop on different dates of sowing especially under delayed onset of monsoon is discussed.

\section{MATERIALS AND METHODS}

Six sunflower field experiments with the variety SS-56 were conducted during kharif 1999 to 2004 seasons on semi-arid vertisols at Solapur. The field experiments were conducted with treatments comprising combinations of 4 dates of sowing (DOS), 3 moisture conservation (MC) methods and 3 levels of $\mathrm{N}$ and $\mathrm{P}$ fertilizer. The crop was sown during the $28^{\text {th }}$ standard meteorological week (SMW) $19-15$ July), $30^{\text {th }}$ SMW (23-29 July), $32^{\text {nd }}$ SMW (6-12 August) and $34^{\text {th }}$ SMW (21-26 August) in each kharif season. The MC methods tested were ridges and furrows, skip row with furrow and flat bed in each season. Three levels of fertilizer $\mathrm{N}$ and $\mathrm{P}$ were applied in the study, at 40-20, 50-25 and 60-30 kg/ha. All conventional agronomic practices were applied in the field experiments.

Table 1: Dates of sowing and harvest, rainfall and sunflower growing season during 1999 to 2004 at Solapur

\begin{tabular}{|c|c|c|c|c|c|}
\hline Year & SMW & Date of sowing & Date of harvest & Rainfall $(\mathrm{mm})$ & Growing season \\
\hline \multirow{4}{*}{1999} & 28 & 9-7-1999 & $11-10-1999$ & 372.7 & 95 \\
\hline & 30 & 23-7-1999 & $25-10-1999$ & 226.4 & 95 \\
\hline & 32 & 10-8-1999 & $15-11-1999$ & 173.1 & 98 \\
\hline & 34 & 21-8-1999 & 4-12-1999 & 168.4 & 106 \\
\hline \multirow{4}{*}{2000} & 28 & $10-7-2000$ & $30-9-2000$ & 369.5 & 83 \\
\hline & 30 & $29-7-2000$ & $15-11-2000$ & 391.5 & 120 \\
\hline & 32 & $11-8-2000$ & $15-11-2000$ & 293.7 & 97 \\
\hline & 34 & $25-8-2000$ & $20-11-2000$ & 194.6 & 88 \\
\hline \multirow{4}{*}{2001} & 28 & $10-7-2001$ & $2-11-2001$ & 423.0 & 116 \\
\hline & 30 & 26-7-2001 & $7-11-2001$ & 515.2 & 105 \\
\hline & 32 & $7-8-2001$ & $15-11-2001$ & 429.2 & 101 \\
\hline & 34 & 24-8-2001 & $18-11-2001$ & 501.7 & 87 \\
\hline \multirow[t]{4}{*}{2002} & 28 & 15-7-2002 & 17-10-2002 & 470.3 & 95 \\
\hline & 30 & 24-7-2002 & $26-10-2002$ & 432.5 & 95 \\
\hline & 32 & $12-8-2002$ & $15-11-2002$ & 229.9 & 96 \\
\hline & 34 & 23-8-2002 & $26-11-2002$ & 217.4 & 96 \\
\hline \multirow{4}{*}{2003} & 28 & $14-7-2003$ & $29-10-2003$ & 248.8 & 108 \\
\hline & 30 & $29-7-2003$ & $1-11-2003$ & 236.8 & 106 \\
\hline & 32 & $11-8-2003$ & $11-11-2003$ & 205.3 & 93 \\
\hline & 34 & 25-8-2003 & $11-11-2003$ & 85.1 & 79 \\
\hline \multirow{4}{*}{2004} & 28 & $9-7-2004$ & $6-10-2004$ & 392.1 & 90 \\
\hline & 30 & 26-7-2004 & $19-10-2004$ & 348.4 & 86 \\
\hline & 32 & $6-8-2004$ & $30-10-2004$ & 243.9 & 86 \\
\hline & 34 & 20-8-2004 & $16-11-2004$ & 228.6 & 89 \\
\hline
\end{tabular}


The soils were vertisols with a soil reaction $(\mathrm{pH})$ of 7.8 and an electrical conductivity of 0.3 . The mean organic carbon (\%) in the soil was $0.4 \%$ with a variation of $9.3 \%$ and soil $\mathrm{N}$ was $140 \mathrm{~kg} / \mathrm{ha}$ with a variation of $16 \%$ during 6 seasons. The mean soil $\mathrm{P}$ was $9.5 \mathrm{~kg} / \mathrm{ha}$ and soil $\mathrm{K}$ was $320 \mathrm{~kg} / \mathrm{ha}$ with a variation of $16.2 \%$ and $10 \%$, respectively, over seasons. The field experiments were conducted in a splitsplit plot design with 3 replications by assigning DOS to the main plot, MC methods to the sub-plot and fertilizer levels to the sub-sub plot. The date of sowing, date of harvest, crop duration and the rainfall received between sowing and harvest during 1999 to 2004 are given in Table 1.

The crop duration ranged from 79 days during 2003 (sown in SMW 34) with a rainfall of $85.1 \mathrm{~mm}$ to 120 days during 2000 (sown in SMW 30) with a rainfall of $391.5 \mathrm{~mm}$. The relations between crop duration and rainfall were determined and were given in Figure 1. It was observed that rainfall had a non-linear influence on crop growing season with a predictability of 0.76 during the 6 seasons of study. The linear effect of rainfall was found to be significantly higher on crop growing season up to about $275 \mathrm{~mm}$ of rainfall.

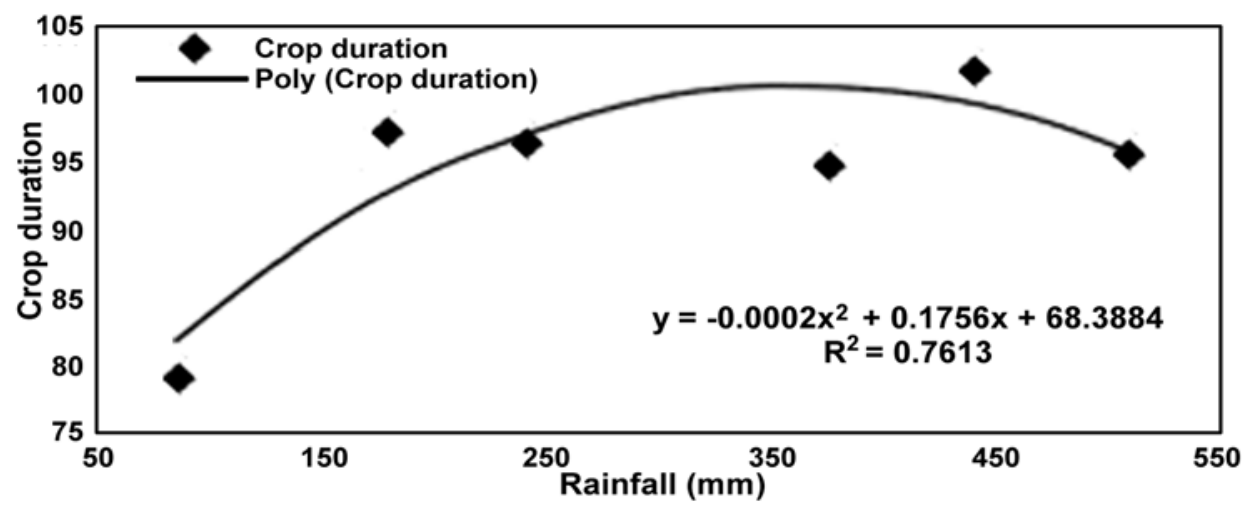

Figure 1: Effect of rainfall on sunflower growing season duration in different years

\section{Descriptive statistics of seed yield, seasonal rainfall, runoff and moisture stress index}

The seed yield of sunflower ranged from 247 to $993 \mathrm{~kg} /$ ha with a mean of 599 $\mathrm{kg} / \mathrm{ha}$ and a variation of $35.9 \%$ over the 6 seasons when sowing during SMW 28 and adopting the ridge and furrow method for moisture conservation. It ranged from 224 to $1067 \mathrm{~kg} / \mathrm{ha}$ with a mean of $516 \mathrm{~kg} / \mathrm{ha}$ and a variation of $43.4 \%$ when sowing during SMW 28 and adopting the skip row with furrow method for moisture conservation. Similarly, the yield ranged from 285 to $697 \mathrm{~kg} / \mathrm{ha}$ with a mean of $468 \mathrm{~kg} /$ ha and a variation of $27.1 \%$ when sowing during SMW 28 and adopting the flat bed method for moisture conservation. The seasonal rainfall ranged between 248.8 to $470.3 \mathrm{~mm}$. The runoff ranged between 2.8 to $94.7 \mathrm{~mm}$, while MSI ranged from 0.231 to 0.693 under the ridge and furrow system. Similarly, the runoff was 
between 7.4 to $131.7 \mathrm{~mm}$ under the skip row with furrow method and 9.5 to 146.2 $\mathrm{mm}$ under the flat bed system, while the corresponding MSI were 0.233 to 0.7 and 0.246 to 0.703 under SMW 28 .

When sowing was done during SMW 30, the seed yield of sunflower ranged from 167 to $643 \mathrm{~kg} / \mathrm{ha}$ with a mean of $334 \mathrm{~kg} / \mathrm{ha}$ and a variation of $37.2 \%$ under the ridge and furrow system. It ranged from 155 to $512 \mathrm{~kg} / \mathrm{ha}$ with a mean of $304 \mathrm{~kg} / \mathrm{ha}$ and a variation of $39.3 \%$ under the skip row with furrow method for moisture conservation. Similarly, the yield ranged from 141 to $486 \mathrm{~kg} / \mathrm{ha}$ with a mean of $295 \mathrm{~kg} /$ ha and a variation of $37.4 \%$ under the flat bed system. The seasonal rainfall ranged between 226.4 to $515.2 \mathrm{~mm}$. The runoff ranged between 4.2 to $91.8 \mathrm{~mm}$, while MSI ranged from 0.196 to 0.616 under the ridge and furrow system. Similarly, the runoff was between 12.7 and $129.8 \mathrm{~mm}$ under skip row with furrow and 14.8 to 153 $\mathrm{mm}$ under the flat bed system, while the corresponding MSI were 0.196 to 0.626 and 0.224 to 0.628 under SMW 30 .

When sowing was done during SMW 32, the seed yield of sunflower ranged from 93 to $653 \mathrm{~kg} / \mathrm{ha}$ with a mean of $351 \mathrm{~kg} / \mathrm{ha}$ and a variation of $48.4 \%$ under the ridge and furrow system. It ranged from 87 to $601 \mathrm{~kg} / \mathrm{ha}$ with a mean of $300 \mathrm{~kg} / \mathrm{ha}$ and a variation of $60 \%$ under skip row with furrow method for moisture conservation. Similarly, the yield ranged from 93 to $711 \mathrm{~kg} / \mathrm{ha}$ with a mean of $305 \mathrm{~kg} / \mathrm{ha}$ and a variation of $70.7 \%$ under the flat bed system. The seasonal rainfall ranged between 173.1 and $429.2 \mathrm{~mm}$. The runoff ranged between 5.7 and $88.6 \mathrm{~mm}$, while MSI ranged from 0.32 to 0.644 under the ridge and furrow system. Similarly, the runoff was between 14.7 and $122.1 \mathrm{~mm}$ under skip row with furrow and 27.7 to $136.5 \mathrm{~mm}$ under the flat bed system, while the corresponding MSI were 0.32 to 0.658 and 0.323 to 0.679 under SMW 32 .

When sowing was done during SMW 34, the seed yield of sunflower ranged from 67 to $785 \mathrm{~kg} / \mathrm{ha}$ with a mean of $377 \mathrm{~kg} / \mathrm{ha}$ and a variation of $47.4 \%$ under the ridge and furrow system. It ranged from 129 to $531 \mathrm{~kg} / \mathrm{ha}$ with a mean of $303 \mathrm{~kg} / \mathrm{ha}$ and a variation of $38.2 \%$ under skip row with furrow method for moisture conservation. Similarly, the yield ranged from 126 to $607 \mathrm{~kg} / \mathrm{ha}$ with a mean of $322 \mathrm{~kg} / \mathrm{ha}$ and a variation of $50.1 \%$ under the flat bed system. During this period, the seasonal rainfall ranged between 85.1 and $501.7 \mathrm{~mm}$. The runoff ranged between 0.3 and $98.7 \mathrm{~mm}$, while MSI ranged from 0.471 to 0.698 under the ridge and furrow system. Similarly, the runoff was between 2.4 and $138.5 \mathrm{~mm}$ under skip row with furrow and from 10.7 to $181.2 \mathrm{~mm}$ under the flat bed system, while the corresponding MSI were 0.471 to 0.707 and 0.471 to 0.727 under SMW 34 .

The descriptive statistics of range, mean, standard deviation, standard error of mean and coefficient of variation of seed yield, seasonal rainfall, runoff and crop season soil moisture stress index under the 12 combinations of sowing dates and moisture conservation methods are given in Table 2. A graphic plot of mean against coefficient of variation is given in Figure 2 ( $a$ - for soil moisture stress index, b - for seasonal rainfall, $\mathrm{c}$ - for runoff and d - for sunflower seed yield under different combinations of dates of sowing and moisture conservation methods). It was observed that higher soil moisture stress, seasonal rainfall, runoff and seed yield occurred 
with lower variation and vice versa during different seasons. Out of the 12 combinations of dates of sowing and moisture conservation methods, there were no situations of high mean with high variation in moisture stress index, seasonal rainfall and seed yield in either year, except for one case in runoff as indicated in Figure 2 (c). In fact, about 6 cases existed under low mean with high variation for moisture stress index, 2 out of 4 cases under high mean with high variation for rainfall, 4 cases each under low mean with either low or high variation for runoff, and about 7 cases under low mean with low variation for seed yield for different combinations of dates of sowing and moisture conservation methods, as given in Figure 2 for different parameters.
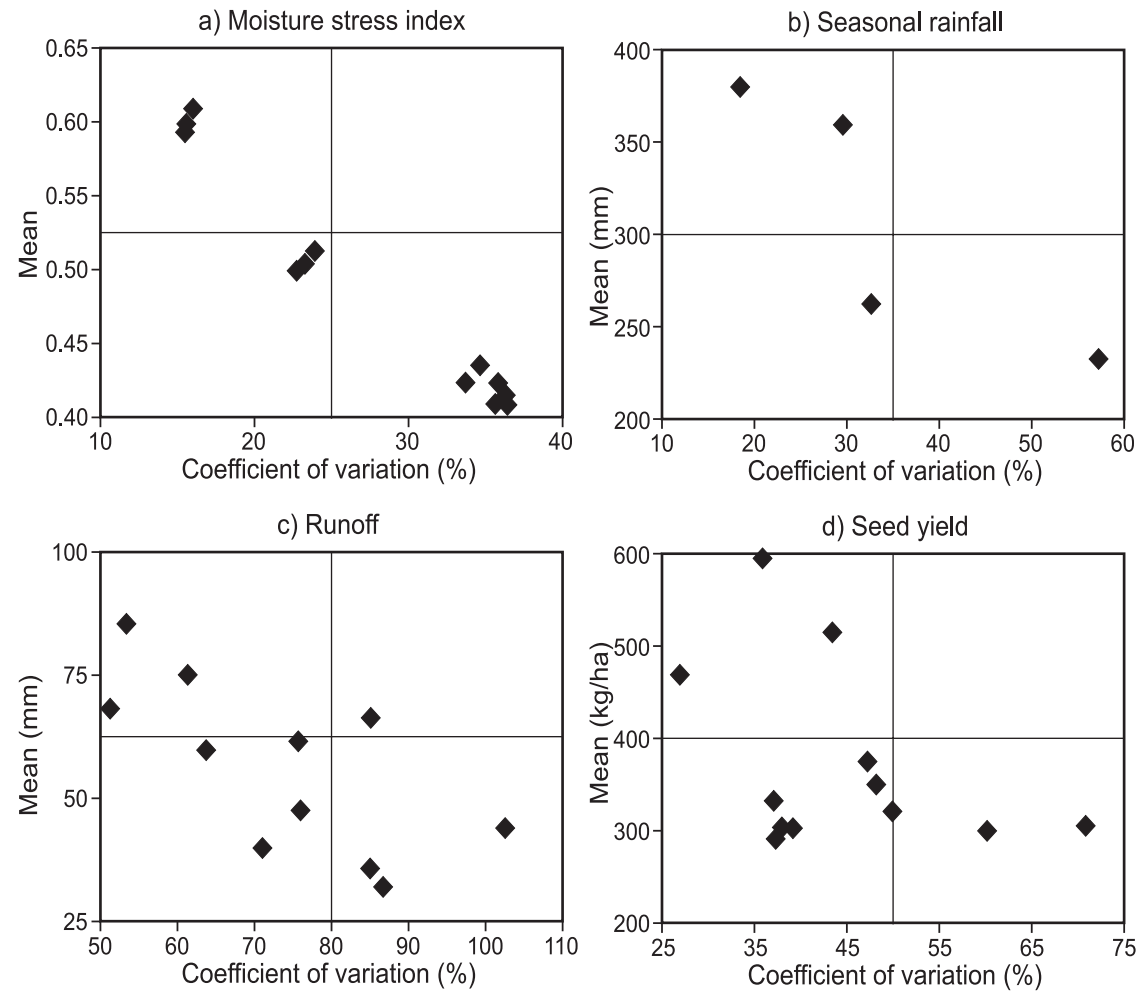

Figure 2: Mean and variation moisture stress index, rainfall, runoff and sunflower seed yield at Solapur

\section{RESULTS AND DISCUSSION}

\section{Analysis of variance of seed yield and sustainability of treatments}

Based on the analysis of variance (ANOVA) of seed yield attained under different treatments in different years, it was shown that the sowing dates differed significantly in each season. Significantly high seed yields were obtained when sowing on 
Table 2: Descriptive statistics of seed yield and other variables in sunflower at Solapur

\begin{tabular}{|c|c|c|c|c|c|c|}
\hline Treatment & Variable & Minimum & Maximum & Mean & Sem & $\mathrm{CV}$ \\
\hline \multirow{4}{*}{ D1 M1 } & SY & 247 & 993 & 599 & 50.6 & 35.9 \\
\hline & RF & 248.8 & 470.3 & 379.4 & 16.4 & 18.4 \\
\hline & RO & 2.8 & 94.7 & 36.1 & 7.2 & 84.9 \\
\hline & MSI & 0.231 & 0.693 & 0.415 & 0.036 & 36.3 \\
\hline \multirow{4}{*}{ D1 M2 } & SY & 224 & 1067 & 516 & 52.9 & 43.4 \\
\hline & RF & 248.8 & 470.3 & 379.4 & 16.4 & 18.4 \\
\hline & RO & 7.4 & 131.7 & 61.9 & 11.1 & 75.8 \\
\hline & MSI & 0.233 & 0.700 & 0.424 & 0.036 & 36.0 \\
\hline \multirow{4}{*}{ D1 M3 } & SY & 285 & 697 & 468 & 29.9 & 27.1 \\
\hline & RF & 248.8 & 470.3 & 379.4 & 16.4 & 18.4 \\
\hline & RO & 9.5 & 146.2 & 75.4 & 10.9 & 61.3 \\
\hline & MSI & 0.246 & 0.703 & 0.435 & 0.036 & 34.7 \\
\hline \multirow{4}{*}{ D2 M1 } & SY & 167 & 643 & 334 & 29.2 & 37.2 \\
\hline & RF & 226.4 & 515.2 & 358.5 & 24.9 & 29.5 \\
\hline & RO & 4.2 & 91.8 & 40.4 & 6.8 & 71.1 \\
\hline & MSI & 0.196 & 0.616 & 0.409 & 0.035 & 36.0 \\
\hline \multirow{4}{*}{ D2 M2 } & SY & 155 & 512 & 304 & 28.2 & 39.3 \\
\hline & RF & 226.4 & 515.2 & 358.5 & 24.9 & 29.5 \\
\hline & RO & 12.7 & 129.8 & 60.3 & 9.1 & 63.9 \\
\hline & MSI & 0.196 & 0.626 & 0.411 & 0.035 & 36.4 \\
\hline \multirow{4}{*}{ D2 M3 } & SY & 141 & 486 & 295 & 26.0 & 37.4 \\
\hline & RF & 226.4 & 515.2 & 358.5 & 24.9 & 29.5 \\
\hline & RO & 14.8 & 153.0 & 85.9 & 10.8 & 53.3 \\
\hline & MSI & 0.224 & 0.628 & 0.424 & 0.034 & 33.8 \\
\hline \multirow{4}{*}{ D3 M1 } & SY & 93 & 653 & 351 & 40.1 & 48.4 \\
\hline & RF & 173.1 & 429.2 & 262.5 & 20.2 & 32.6 \\
\hline & RO & 5.7 & 88.6 & 32.5 & 6.6 & 86.6 \\
\hline & MSI & 0.320 & 0.644 & 0.499 & 0.027 & 22.9 \\
\hline \multirow{4}{*}{ D3 M2 } & SY & 87 & 601 & 300 & 42.3 & 60.0 \\
\hline & RF & 173.1 & 429.2 & 262.5 & 20.2 & 32.6 \\
\hline & RO & 14.7 & 122.1 & 48.0 & 8.6 & 75.9 \\
\hline & MSI & 0.320 & 0.658 & 0.503 & 0.028 & 23.3 \\
\hline \multirow{4}{*}{ D3 M3 } & SY & 93 & 711 & 305 & 50.8 & 70.7 \\
\hline & RF & 173.1 & 429.2 & 262.5 & 20.2 & 32.6 \\
\hline & RO & 27.7 & 136.5 & 68.6 & 8.3 & 51.2 \\
\hline & MSI & 0.323 & 0.679 & 0.512 & 0.029 & 23.9 \\
\hline \multirow{4}{*}{ D4 M1 } & SY & 67 & 785 & 377 & 42.1 & 47.4 \\
\hline & RF & 85.1 & 501.7 & 232.6 & 31.3 & 57.1 \\
\hline & RO & 0.3 & 98.7 & 30.3 & 7.8 & 108.7 \\
\hline & MSI & 0.471 & 0.698 & 0.593 & 0.021 & 15.4 \\
\hline \multirow{4}{*}{ D4 M2 } & SY & 129 & 531 & 303 & 27.3 & 38.2 \\
\hline & RF & 85.1 & 501.7 & 232.6 & 31.3 & 57.1 \\
\hline & RO & 2.4 & 138.5 & 44.3 & 10.7 & 102.4 \\
\hline & MSI & 0.471 & 0.707 & 0.597 & 0.022 & 15.5 \\
\hline \multirow{4}{*}{ D4 M3 } & SY & 126 & 607 & 322 & 38.0 & 50.1 \\
\hline & RF & 85.1 & 501.7 & 232.6 & 31.3 & 57.1 \\
\hline & RO & 10.7 & 181.2 & 66.6 & 13.3 & 85.0 \\
\hline & MSI & 0.471 & 0.727 & 0.608 & 0.023 & 15.9 \\
\hline \multicolumn{3}{|c|}{ MSI: Soil moisture stress index } & \multicolumn{2}{|c|}{ SY: Seed yield (kg/ha) } & \multicolumn{2}{|c|}{ RF: Rainfall (mm) } \\
\hline \multicolumn{3}{|c|}{ D1: SMW 28 (9-15 July) } & \multicolumn{2}{|c|}{ D3: SMW 32 (6-12 August) } & \multicolumn{2}{|c|}{ RO: Runoff (mm) } \\
\hline \multicolumn{3}{|c|}{ D2: SMW 30 (23-29 July) } & D4: SMW 34 & -26 August & $\begin{array}{l}\text { M1: Ridge } \\
\text { M2: Skip ro }\end{array}$ & $\begin{array}{l}\text { ow } \\
\text { furrow }\end{array}$ \\
\hline Sem: Stanc & rror of $\mathrm{me}$ & & CV: Coefficient & ariation (\%) & M3: Flat be & \\
\hline
\end{tabular}


$9^{\text {th }}$ July in all the 6 seasons, with a mean yield of $528 \mathrm{~kg} / \mathrm{ha}$. The other 3 dates of sowing were on a par with each other based on the pooled analysis. However, in individual seasons, $1^{\text {st }}$ DOS was followed by $2^{\text {nd }}$ DOS in 2002 and $4^{\text {th }}$ DOS in 1999. Further, $3^{\text {rd }}$ DOS was found to be superior in 2001, 2003 and 2004. The moisture conservation methods were found to be significantly different only in 2000 and 2002 seasons, while they were on a par in the other 4 seasons of study. The 3 combinations of $\mathrm{N}$ and $\mathrm{P}$ fertilizers were significantly different only in 2000, 2001 and 2002 seasons, while they were found to be on a par in the remaining 3 seasons. The results of ANOVA for seed yield are given in Table 3.

Table 3: Analysis of variance of sunflower seed yield during 1999 - 2004 at Solapur

\begin{tabular}{|c|c|c|c|c|c|c|c|c|}
\hline \multirow{2}{*}{$\begin{array}{l}\text { Treatment } \\
\text { Sowing date }\end{array}$} & \multicolumn{6}{|c|}{ Seed yield (kg/ha) } & \multirow{2}{*}{ Mean } & \multirow{2}{*}{ SYI } \\
\hline & 1999 & 2000 & 2001 & 2002 & 2003 & 2004 & & \\
\hline SMW 28 (9-15 July) & 495 & 699 & 346 & 632 & 298 & 696 & 528 & 0.75 \\
\hline SMW 30 (23-29 July) & 201 & 209 & 296 & 489 & 261 & 410 & 311 & 0.40 \\
\hline SMW 32 (6 -12 August) & 220 & 229 & 513 & 100 & 279 & 571 & 319 & 0.28 \\
\hline SMW 34 (21-26 August) & 402 & 271 & 465 & 239 & 147 & 479 & 334 & 0.37 \\
\hline Mean & 329 & 352 & 405 & 365 & 246 & 539 & 373 & 0.45 \\
\hline S.Em. & 44 & 23 & 16 & 6 & 21 & 36 & 25 & \\
\hline C.D.(0.05) & 140 & 74 & 54 & 20 & 70 & 118 & 81 & \\
\hline \multicolumn{9}{|l|}{ Moisture conservation } \\
\hline Ridges \& furrows & 378 & 449 & 454 & 405 & 250 & 555 & 371 & 0.52 \\
\hline Skip row with furrow & 268 & 350 & 379 & 355 & 247 & 553 & 305 & 0.43 \\
\hline Flat bed & 334 & 256 & 381 & 334 & 250 & 528 & 294 & 0.41 \\
\hline Mean & 329 & 352 & 405 & 365 & 246 & 539 & 373 & 0.45 \\
\hline S.Em. & 34 & 10 & 22 & 10 & 15 & 17 & 18 & \\
\hline C.D. (0.05) & NS & 32 & NS & 33 & NS & NS & 60 & \\
\hline \multicolumn{9}{|l|}{ Fertilizer N \& P doses $(\mathrm{kg} / \mathrm{ha})$} \\
\hline $40: 20$ & 296 & 318 & 329 & 317 & 248 & 506 & 295 & 0.41 \\
\hline $50: 25$ & 334 & 351 & 411 & 366 & 265 & 539 & 329 & 0.46 \\
\hline $60: 30$ & 351 & 387 & 474 & 412 & 234 & 572 & 346 & 0.48 \\
\hline Mean & 329 & 352 & 405 & 365 & 246 & 539 & 373 & 0.45 \\
\hline S.Em. & 18 & 5 & 11 & 7 & 14 & 20 & 13 & \\
\hline C.D.(0.05) & NS & 15 & 32 & 19 & NS & NS & 45 & \\
\hline
\end{tabular}

Sustainability index of a treatment or a rainfed practice can be derived based on the relations of seasonal rainfall and crop yields achieved in different seasons (Vittal et al., 2003). Based on the estimates of sustainability yield index (SYI) derived for different treatments, it was observed that sunflower sowing in SMW-28 has a maximum sustainability of 0.75 during the 6 seasons, followed by SMW-30, SMW-34 and SMW-32 with 0.40, 0.37 and 0.28, respectively. Among the three moisture conservation treatments, ridges and furrows had high sustainability of 0.52 , followed by skip row with furrow with a SYI of 0.43 and the flat bed method 
with 0.41 during the 6 seasons. Among the three levels of $\mathrm{N}$ and $\mathrm{P}$ combinations tested for sunflower, the application of $60 \mathrm{~kg} \mathrm{~N}+30 \mathrm{~kg} \mathrm{P}_{2} \mathrm{O}_{5} / \mathrm{ha}$ had a maximum sustainability of 0.48 , while $40 \mathrm{~kg} \mathrm{~N}+20 \mathrm{~kg} \mathrm{P}_{2} \mathrm{O}_{5} /$ ha had a minimum SYI of 0.41 , as given in Table 3.

\section{Relation between seed yield, seasonal rainfall, runoff and soil moisture stress index}

Estimates of correlation were derived among seed yield, seasonal rainfall, runoff and crop season soil moisture stress index under each of the 12 combinations of sowing dates and moisture conservation methods and are given in Table 4.

Table 4: Correlation between sunflower seed yield, seasonal rainfall, runoff, soil moisture stress index and fertilizer variables at Solapur

\begin{tabular}{|c|c|c|c|c|c|c|}
\hline \multirow{2}{*}{ Variable 1} & \multirow{2}{*}{ Variable 2} & \multirow{2}{*}{ MC } & \multicolumn{4}{|c|}{ Correlation between variables for different sowing dates } \\
\hline & & & $\mathrm{D} 1$ & $\mathrm{D} 2$ & D3 & D4 \\
\hline & & M1 & $0.47^{\star}$ & $0.50 *$ & 0.21 & $0.84^{\star \star}$ \\
\hline \multirow[t]{3}{*}{ SY } & RF & M2 & 0.34 & 0.38 & $0.61^{\star \star}$ & $0.62^{\star \star}$ \\
\hline & & M3 & $0.54^{\star}$ & 0.26 & $0.57^{\star}$ & 0.16 \\
\hline & & M1 & -0.28 & 0.41 & 0.21 & $0.80 * \star$ \\
\hline \multirow[t]{3}{*}{ SY } & RO & M2 & -0.17 & 0.41 & $0.64^{\star \star}$ & $0.61 * *$ \\
\hline & & M3 & -0.17 & $0.47^{*}$ & $0.69 * *$ & 0.19 \\
\hline & & M1 & -0.32 & $-0.61^{\star \star}$ & -0.22 & -0.41 \\
\hline \multirow[t]{3}{*}{ SY } & MSI & M2 & $-0.49^{\star}$ & $-0.60 * \star$ & $-0.62 * \star$ & $-0.47^{\star}$ \\
\hline & & M3 & -0.32 & 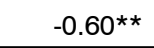 & $-0.69 \star \star \star$ & -0.08 \\
\hline & & M1 & 0.16 & 0.20 & 0.18 & 0.14 \\
\hline \multirow[t]{3}{*}{ SY } & FN & M2 & 0.24 & 0.13 & 0.15 & 0.26 \\
\hline & & M3 & 0.36 & 0.22 & 0.11 & 0.08 \\
\hline & & M1 & 0.16 & 0.20 & 0.18 & 0.14 \\
\hline \multirow[t]{3}{*}{ SY } & FP & M2 & 0.24 & 0.13 & 0.15 & 0.26 \\
\hline & & M3 & 0.36 & 0.22 & 0.11 & 0.08 \\
\hline & & M1 & $0.47^{\star}$ & $0.76^{\star \star}$ & $0.82^{\star \star}$ & 0.90 ** \\
\hline \multirow[t]{3}{*}{$\mathrm{RF}$} & RO & M2 & $0.63^{\star *}$ & $0.81^{* *}$ & $0.84^{\star *}$ & $0.93^{* *}$ \\
\hline & & M3 & $0.52^{\star}$ & $0.84^{\star \star}$ & $0.84^{\star \star}$ & $0.95^{\star *}$ \\
\hline & & $\mathrm{M} 1$ & -0.33 & $-0.83^{\star \star}$ & $-0.72^{\star \star}$ & $-0.72^{\star \star}$ \\
\hline \multirow[t]{3}{*}{$\mathrm{RF}$} & MSI & M2 & -0.30 & $-0.83^{\star \star}$ & $-0.73^{\star \star}$ & $-0.73^{* *}$ \\
\hline & & M3 & -0.35 & $-0.84 * \star$ & $-0.74 * \star$ & $-0.75^{\star *}$ \\
\hline & & $\mathrm{M} 1$ & -0.39 & $-0.89 \star \star$ & $-0.77^{\star \star}$ & $-0.75^{\star \star}$ \\
\hline \multirow[t]{2}{*}{ RO } & MSI & M2 & $-0.47^{\star}$ & $-0.92 * *$ & $-0.79 * \star$ & $-0.76^{\star *}$ \\
\hline & & M3 & $-0.59 * \star$ & $-0.93^{\star *}$ & $-0.79 * \star$ & $-0.81 * \star$ \\
\hline \multicolumn{4}{|c|}{${ }^{\star}$ and ${ }^{\star \star}$ indicate significance at 5 and $1 \%$ levels } & \multicolumn{3}{|c|}{ SY: Seed yield $(\mathrm{kg} / \mathrm{ha})$} \\
\hline \multicolumn{4}{|c|}{ SMI: Soil moisture stress index } & \multicolumn{3}{|c|}{ RF: Rainfall (mm) } \\
\hline \multicolumn{4}{|c|}{ D1: SMW 28 (9-15 July) } & \multicolumn{3}{|c|}{ D2: SMW 30 (23-29 July) } \\
\hline \multicolumn{4}{|c|}{ D3: SMW 32 (6-12 August) } & \multicolumn{3}{|c|}{ D4: SMW 34 (21-26 August) } \\
\hline \multicolumn{4}{|c|}{ M1: Ridge \& Furrow } & \multicolumn{3}{|c|}{ M2: Skip row with furrow } \\
\hline \multicolumn{3}{|c|}{ M3: Flat bed } & & \multicolumn{3}{|c|}{ RO: Runoff (mm) } \\
\hline \multicolumn{3}{|c|}{ MC: Moisture conservation } & : Fertilizer $\mathrm{N}$ & \multicolumn{3}{|c|}{ FP: Fertilizer P } \\
\hline
\end{tabular}


The analysis indicated that seed yield had a positive relation with rainfall in all 4 DOS. The relation was higher for flat bed in $1^{\text {st }}$ DOS, than for ridge $\&$ furrow in $2^{\text {nd }}$ DOS and skip row with furrow in $3^{\text {rd }}$ and $4^{\text {th }}$ DOS. Seed yield was negatively related with runoff in $1^{\text {st }}$ DOS, while positively related in the other 3 DOS. The relation was relatively higher under ridge $\&$ furrow system in $1^{\text {st }}$ DOS (negative) and $4^{\text {th }}$ DOS (positive) than under flat bed in $2^{\text {nd }}$ and $3^{\text {rd }}$ DOS. Negative relation of moisture stress index was found with seed yield in all 12 combinations of DOS and MC indicating a higher relation under skip row with furrow in $1^{\text {st }}, 2^{\text {nd }}$ and $4^{\text {th }}$ DOS, and flat bed in $3^{\text {rd }}$ DOS. The relation between seasonal rainfall and runoff was positive, while moisture stress index had a negative relation with both rainfall and runoff under all the 3 moisture conservation methods in 4 different sowing dates.

These results indicated that in a maximum number out of 12 combinations of dates of sowing and moisture conservation methods, a moderate seed yield of 250 to $500 \mathrm{~kg} / \mathrm{ha}$ was obtained with a moderate rainfall of 250 to $500 \mathrm{~mm}$, moderate runoff of 30 to $60 \mathrm{~mm}$ and moderate moisture stress index of 0.25 to 0.50 . In 5 cases of each moderate ( 0.25 to 0.50$)$ and high moisture stress index (0.50 to 0.75 ), moderate seed yields were attained, while only in 2 cases of moderate moisture stress index, high yields of more than $500 \mathrm{~kg} / \mathrm{ha}$ were attained.

Table 5: Grouping of seed yield of sunflower at different quantities of rainfall, runoff and moisture stress at Solapur

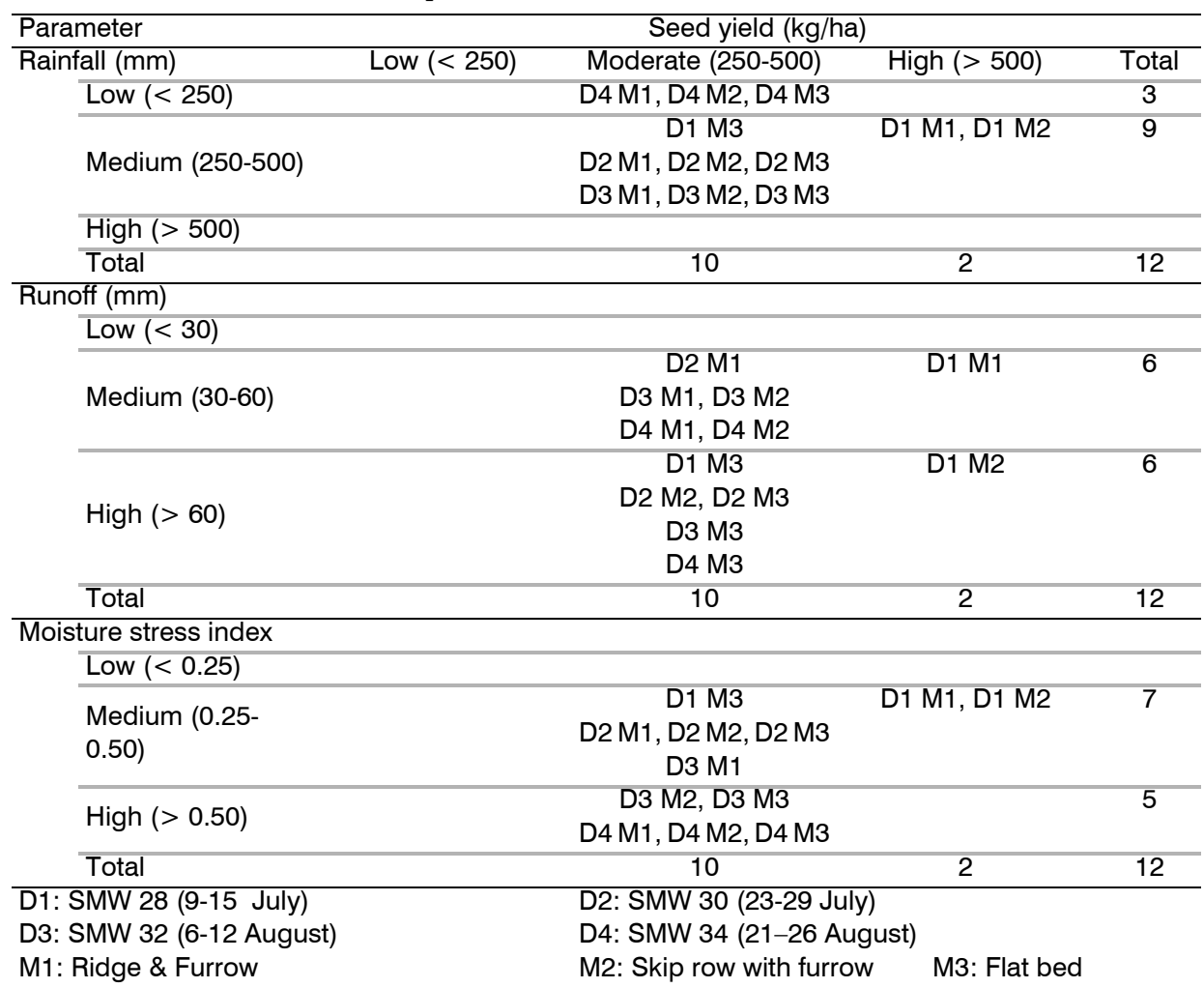


Seed yield was moderate in 3 cases of low rainfall of less than $250 \mathrm{~mm}, 7$ cases of medium rainfall of 250 to $500 \mathrm{~mm}$, while high yield of more than $500 \mathrm{~kg} / \mathrm{ha}$ was obtained under medium rainfall situations. When the runoff was medium, from 30 to $60 \mathrm{~mm}$, moderate seed yield was obtained in 5 cases and high yield in one case. Similar numbers of cases were obtained in moderate and high categories, when the runoff was above $60 \mathrm{~mm}$. Table 5 shows the grouping of seed yields in low, moderate and high categories at low, medium and high rainfall, runoff and moisture stress index.

\section{Regression models of seed yield via seasonal rainfall, runoff, soil moisture stress index and fertilizer variables}

Multiple regression models of sunflower seed yield via seasonal rainfall, runoff, crop season soil moisture stress index, linear and quadratic terms of fertilizer $\mathrm{N}$ and $\mathrm{P}$, along with interaction of fertilizer and soil moisture stress index were calibrated for each of the 12 combinations of sowing dates and moisture conservation methods. The estimates of regression coefficients $(\beta)$, coefficient of predictability $\left(\mathrm{R}^{2}\right)$ and model based prediction error $(\delta)$ are given in Table 6 . Rainfall and runoff were found to significantly influence seed yield under all the 3 methods of moisture conservation tested when crop was sown on the $1^{\text {st }}$ date of sowing, i.e., under SMW 28. Seasonal rainfall was found to be significant when sowing under SMW 30 and adopting the flat bed method for moisture conservation. The predictability ranged from a low of 0.12 for predicting seed yield based on sowing done during SMW 32 and using the ridge and furrow method for moisture conservation to a maximum of 0.91 for predicting seed yield based on sowing done during SMW 28 and adopting the flat bed method for moisture conservation. Based on the above range of predictability of seed yield, the model based prediction error was found to be in the range of $198.7 \mathrm{~kg} / \mathrm{ha}$ (SMW 32 with ridges and furrows) to $47.3 \mathrm{~kg} / \mathrm{ha}$ (SMW 28 with flat bed).

The seasonal rainfall had a positive influence on seed yield when sowing during SMW 28, 30, 32 and 34 and adopting the ridge and furrow method. Under the skip row with furrow system, it had a positive influence on seed yield under all sowing dates except SMW 30. Under the flat bed method, it had a negative influence on seed yield under all sowing dates except SMW 28.

Runoff has a negative influence on seed yield when sown during SMW 28 and 30 and positive influence when sown during SMW 32 under all the 3 methods of moisture conservation. However, when sown during SMW 34, runoff has a negative influence on seed yield under the ridge and furrow method, and positive influence under the skip row with furrow and flat bed methods.

The soil moisture stress index was found to have a negative influence on seed yield when sowing during SMW 30 and positive influence when sowing during SMW 34 and adopting any of the 3 methods of moisture conservation. However, the relation was positive under skip row with furrow and negative under the ridge and fur- 
row and flat bed methods when sowing during SMW 28. Similarly, it was positive under the ridge and furrow and skip row with furrow methods and negative under the flat bed method when sowing during SMW 32.

Except for under the ridge and furrow method (when sowing during SMW 30), the skip row with furrow method (when sowing during SMW 28) and the flat bed method (when sowing during SMW 30, 32 and 34), the $\mathrm{N}$ and $\mathrm{P}$ nutrients were found to have the + /- response type, a positive sign indicating an increasing linear response (positive influence on yield), a negative sign indicating a decreasing quadratic response (negative influence on yield). Out of 8 response types, the occurrence of the +/- response type is essential for optimizing fertilizer doses at varying soil moisture stress index values (Maruthi Sankar, 1986).

Table 6: Multiple regression models of sunflower seed yield via rainfall, runoff, crop season moisture stress index and applied N and P fertilizer at Solapur

\begin{tabular}{|c|c|c|c|c|}
\hline DOS & $\mathrm{MC}$ & Multiple regression equation & $\mathrm{R}^{2}$ & $\mathrm{~d}$ \\
\hline D1 & M1 & $\begin{array}{l}\mathrm{Y}=-2149+2.115^{\star *}(\mathrm{RF})-5.326^{* *}(\mathrm{RO})-303.12(\mathrm{MSI})+90.90(\mathrm{FN})- \\
0.847\left(\mathrm{FN}^{2}\right)+181.81(\mathrm{FP})-3.387\left(\mathrm{FP}^{2}\right)-5.22(\mathrm{FN})(\mathrm{MSI})-10.45(\mathrm{FP})(\mathrm{MSI})\end{array}$ & $0.75^{\star}$ & 140.8 \\
\hline D1 & M2 & $\begin{array}{l}\mathrm{Y}=1316+2.354^{* *}(\mathrm{RF})-4.591{ }^{* *}(\mathrm{RO})+389.31(\mathrm{MSI})-59.34(\mathrm{FN})+0.78 \\
\left(\mathrm{FN}^{2}\right)-118.68(\mathrm{FP})+3.12\left(\mathrm{FP}^{2}\right)-28.68(\mathrm{FN})(\mathrm{MSI})-57.36(\mathrm{FP})(\mathrm{MSI})\end{array}$ & $0.88^{* *}$ & 97.5 \\
\hline D1 & M3 & $\begin{array}{l}=-80+1.503 * *(\mathrm{RF})-2.538 * *(\mathrm{RO})-329.2(\mathrm{MSI})+8.44(\mathrm{FN})-0.018 \\
\left(\mathrm{FN}^{2}\right)+16.88(\mathrm{FP})-0.07\left(\mathrm{FP}^{2}\right)-2.98(\mathrm{FN})(\mathrm{MSI})-5.96(\mathrm{FP})(\mathrm{MSI})\end{array}$ & $0.91 * \star$ & 47.3 \\
\hline D2 & M1 & $\begin{array}{l}\mathrm{Y}=559+0.045(\mathrm{RF})-2.871(\mathrm{RO})-653.1(\mathrm{MSI})+5.40(\mathrm{FN})+0.033 \\
\left(\mathrm{FN}^{2}\right)+10.80(\mathrm{FP})+0.013\left(\mathrm{FP}^{2}\right)-6.69(\mathrm{FN})(\mathrm{MSI})-13.38(\mathrm{FP})(\mathrm{MSI})\end{array}$ & 0.51 & 107.7 \\
\hline D2 & M2 & $\begin{array}{l}\mathrm{Y}=-129-0.314(\mathrm{RF})-2.505(\mathrm{RO})-44.27(\mathrm{MSI})+37.36(\mathrm{FN})-0.255 \\
\left(\mathrm{FN}^{2}\right)+74.72(\mathrm{FP})-1.02\left(\mathrm{FP}^{2}\right)-24.21(\mathrm{FN})(\mathrm{MSI})-48.42(\mathrm{FP})(\mathrm{MSI})\end{array}$ & 0.60 & 93.8 \\
\hline D2 & M3 & $\begin{array}{l}\mathrm{Y}=981-0.815^{*}(\mathrm{RF})-0.896(\mathrm{RO})-778.6(\mathrm{MSI})+1.34(\mathrm{FN})+0.054 \\
\left(\mathrm{FN}^{2}\right)+2.68(\mathrm{FP})+0.217\left(\mathrm{FP}^{2}\right)-9.13(\mathrm{FN})(\mathrm{MSI})-18.26(\mathrm{FP})(\mathrm{MSI})\end{array}$ & 0.65 & 81.6 \\
\hline D3 & M1 & $\begin{array}{l}\mathrm{Y}=-688+0.13(\mathrm{RF})+0.378(\mathrm{RO})+1432.7(\mathrm{MSI})+23.81(\mathrm{FN})-0.042 \\
\left(\mathrm{FN}^{2}\right)+47.62(\mathrm{FP})-0.167\left(\mathrm{FP}^{2}\right)-32.27(\mathrm{FN})(\mathrm{MSI})-64.53(\mathrm{FP})(\mathrm{MSI})\end{array}$ & 0.12 & 198.7 \\
\hline D3 & M2 & $\begin{array}{l}\mathrm{Y}=-1070+0.415(\mathrm{RF})+1.217(\mathrm{RO})+821.99(\mathrm{MSI})+41.75(\mathrm{FN})-0.26 \\
\left(\mathrm{FN}^{2}\right)+83.50(\mathrm{FP})-1.04\left(\mathrm{FP}^{2}\right)-25.12(\mathrm{FN})(\mathrm{MSI})-50.23(\mathrm{FP})(\mathrm{MSI})\end{array}$ & 0.50 & 158.1 \\
\hline D3 & M3 & $\begin{array}{l}\mathrm{Y}=1542-0.405(\mathrm{RF})+3.131(\mathrm{RO})-602.73(\mathrm{MSI})-44.37(\mathrm{FN})+0.482 \\
\left(\mathrm{FN}^{2}\right)-88.74(\mathrm{FP})+1.927\left(\mathrm{FP}^{2}\right)-2.15(\mathrm{FN})(\mathrm{MSI})-4.29(\mathrm{FP})(\mathrm{MSI})\end{array}$ & 0.56 & 177.0 \\
\hline D4 & M1 & $\begin{array}{l}\mathrm{Y}=-1621+2.627(\mathrm{RF})-4.858(\mathrm{RO})+1821.7(\mathrm{MSI})+29.80(\mathrm{FN})-0.127 \\
\left(\mathrm{FN}^{2}\right)+59.60(\mathrm{FP})-0.507\left(\mathrm{FP}^{2}\right)-23.99(\mathrm{FN})(\mathrm{MSI})-47.98(\mathrm{FP})(\mathrm{MSI})\end{array}$ & $0.81 *$ & 97.2 \\
\hline D4 & M2 & $\begin{array}{l}\mathrm{Y}=-2283+0.344(\mathrm{RF})+0.577(\mathrm{RO})+2015.1(\mathrm{MSI})+72.71(\mathrm{FN})-0.45 \\
\left(\mathrm{FN}^{2}\right)+145.42(\mathrm{FP})-1.81\left(\mathrm{FP}^{2}\right)-40.10(\mathrm{FN})(\mathrm{MSI})-80.21(\mathrm{FP})(\mathrm{MSI})\end{array}$ & 0.55 & 96.6 \\
\hline D4 & M3 & $\begin{array}{l}\mathrm{Y}=-395-5.989(\mathrm{RF})+16.625(\mathrm{RO})+1664.1(\mathrm{MSI})-0.62(\mathrm{FN})+0.036 \\
\left(\mathrm{FN}^{2}\right)-1.24(\mathrm{FP})+0.143\left(\mathrm{FP}^{2}\right)-2.28(\mathrm{FN})(\mathrm{MSI})-4.56(\mathrm{FP})(\mathrm{MSI})\end{array}$ & 0.25 & 173.7 \\
\hline
\end{tabular}

* and ** indicate significance at 5 and $1 \%$ levels
DOS: Date of sowing
MC: Moisture conservation
FN: Fertilizer $\mathrm{N}$
MSI: Soil moisture stress index
FP: Fertilizer $P$
RF: Rainfall $(\mathrm{mm})$
RO: Runoff (mm)
D2: SMW 30 (23-29 July)
D1: SMW 28 (9-15 July)
D4: SMW 34 (21-26 August)
D3: SMW 32 (6-12 August)
M2: Skip row with furrow
M1: Ridge \& Furrow
M3: Flat bed
$\mathrm{R}^{2}$ : Coefficient of determination
$\delta$ : Estimate of error $(\mathrm{kg} / \mathrm{ha})$ 


\section{Optimal fertilizer doses for varying levels of available soil moisture}

Based on multiple regression models, fertilizer adjustment equations of $\mathrm{N}$ and $\mathrm{P}$ as a function of available soil moisture stress index were derived and are given in Table 7. The fertilizer adjustment equations of $\mathrm{N}$ and $\mathrm{P}$ were derived under each model having a positive linear coefficient, a negative quadratic coefficient for a fertilizer variable along with a negative interaction coefficient for fertilizer X soil moisture stress index. This indicates an increasing response at the initial level and diminishing returns at higher levels of fertilizer application. The negative interaction would indicate a higher fertilizer dose at low soil moisture stress index and vice versa for better response of the crop.

Table 7: Fertilizer adjustment equations via crop season moisture stress index for sunflower at Solapur

\begin{tabular}{lcccc}
\hline DOS & Nutrient & Ridge \& furrow & Skip row with furrow & Flat bed \\
\hline D1 & $\mathrm{N}$ & $\mathrm{FN}=53.7-3.08 \mathrm{MSI}$ & $\#$ & $\mathrm{FN}=211.0-74.50 \mathrm{MSI}$ \\
& $\mathrm{P}$ & $\mathrm{FP}=26.8-1.54 \mathrm{MSI}$ & $\#$ & $\mathrm{FP}=105.0-37.20 \mathrm{MSI}$ \\
D2 & $\mathrm{N}$ & $\#$ & $\mathrm{FN}=73.3-47.47 \mathrm{MSI}$ & $\#$ \\
& $\mathrm{P}$ & $\#$ & $\mathrm{FP}=36.6-23.74 \mathrm{MSI}$ & $\#$ \\
D3 & $\mathrm{N}$ & $\mathrm{FN}=198.0-268.90 \mathrm{MSI}$ & $\mathrm{FN}=80.3-48.31 \mathrm{MSI}$ & $\#$ \\
& $\mathrm{P}$ & $\mathrm{FP}=99.0-134.40 \mathrm{MSI}$ & $\mathrm{FP}=40.1-24.15 \mathrm{MSI}$ & $\#$ \\
D4 & $\mathrm{N}$ & $\mathrm{FN}=117.3-94.45 \mathrm{MSI}$ & $\mathrm{FN}=80.8-44.56 \mathrm{MSI}$ & $\#$ \\
& $\mathrm{P}$ & $\mathrm{FP}=58.6-47.22 \mathrm{MSI}$ & $\mathrm{FP}=40.4-22.28 \mathrm{MSI}$ & $\#$ \\
\hline
\end{tabular}

\# indicates calibration not possible due to non-diminishing response of a nutrient

DOS: Date of sowing MSI: Crop season water stress index

D1: SMW 28 (9-15 July) D2: SMW 30 (23-29 July)

D3: SMW 32 (6-12 August) D4: SMW 34 (21-26 August)

FN: Fertilizer nitrogen $\quad$ FP: Fertilizer phosphorus

Using the fertilizer adjustment equations, a ready reckon of optimal $\mathrm{N}$ and $\mathrm{P}$ fertilizer doses at varying levels of soil moisture stress index was worked out and given in Table 8 . The analysis indicated that the optimal $\mathrm{N}$ fertilizer ranged from 53 to $51 \mathrm{~kg} / \mathrm{ha}$ and P fertilizer from 27 to $26 \mathrm{~kg} / \mathrm{ha}$ when the soil moisture stress index ranged from 0.15 to 0.75 and when sowing was performed during SMW $28\left(1^{\text {st }}\right.$ DOS) while adopting the ridge and furrow method. Under the skip row with furrow method, the optimal $\mathrm{N}$ dose ranged from 66 to $38 \mathrm{~kg} / \mathrm{ha}$ and $\mathrm{P}$ dose from 33 to 19 $\mathrm{kg} /$ ha when sowing during SMW 30 ( $2^{\text {nd }}$ DOS $)$ and adopting the skip row with furrow method. Similarly, the optimal fertilizer N has ranged from 73 to $44 \mathrm{~kg} / \mathrm{ha}$ and 36 to $22 \mathrm{~kg} /$ ha when the crop was sown during SMW $32\left(3^{\text {rd }}\right.$ DOS $)$ or SMW $34\left(4^{\text {th }}\right.$ DOS) when the soil moisture stress index ranged from 0.15 to 0.75 . The corresponding $\mathrm{P}$ fertilizer dose ranged from 36 to $22 \mathrm{~kg} / \mathrm{ha}$ under $3^{\text {rd }}$ DOS and 37 to 24 $\mathrm{kg} / \mathrm{ha}$ under $4^{\text {th }}$ DOS. The optimal fertilizer doses under the flat bed method for the crop sown during SMW $28\left(1^{\text {st }}\right.$ DOS) and the ridge and furrow method when the crop was sown during SMW $32\left(3^{\text {rd }}\right.$ DOS $)$ at varying soil moisture stress indices were found to be extrapolable. Thus the study indicated that ridges and furrows is the best method for moisture conservation for sowing during SMW 28, while skip 
row with furrows is the best method for sowing during SMW 30, or 32 or 34 for attaining maximum productivity on semi-arid vertisols.

Table 8: Ready reckon of optimum fertilizer $\mathrm{N}$ and $\mathrm{P}$ doses at varying levels of soil moisture stress index for sunflower at Solapur

\begin{tabular}{|c|c|c|c|c|c|c|c|c|c|c|c|c|}
\hline \multirow{2}{*}{ MSI } & \multicolumn{3}{|c|}{ D1 } & \multicolumn{3}{|c|}{ D2 } & \multicolumn{3}{|c|}{ D3 } & \multicolumn{3}{|c|}{ D4 } \\
\hline & M1 & M2 & M3 & M1 & $\overline{\mathrm{M} 2}$ & M3 & M1 & M2 & $\mathrm{M3}$ & M1 & M2 & $\mathrm{M3}$ \\
\hline \multicolumn{13}{|c|}{ Optimum fertilizer N (kg/ha) } \\
\hline 0.15 & 53 & \# & 200 & $\#$ & 66 & $\#$ & 158 & 73 & \# & 103 & 74 & \# \\
\hline 0.20 & 53 & \# & 196 & \# & 64 & \# & 144 & 71 & \# & 98 & 72 & \# \\
\hline 0.25 & 53 & $\#$ & 192 & $\#$ & 61 & \# & 131 & 68 & \# & 94 & 70 & \# \\
\hline 0.30 & 53 & \# & 189 & \# & 59 & \# & 117 & 66 & \# & 89 & 67 & \# \\
\hline 0.35 & 53 & $\#$ & 185 & $\#$ & 57 & \# & 104 & 63 & $\#$ & 84 & 65 & $\#$ \\
\hline 0.40 & 52 & $\#$ & 181 & $\#$ & 54 & \# & 90 & 61 & $\#$ & 80 & 63 & \# \\
\hline 0.45 & 52 & \# & 177 & \# & 52 & \# & 77 & 59 & \# & 75 & 61 & \# \\
\hline 0.50 & 52 & $\#$ & 174 & $\#$ & 50 & \# & 64 & 56 & $\#$ & 70 & 59 & \# \\
\hline 0.55 & 52 & \# & 170 & \# & 47 & \# & 50 & 54 & \# & 65 & 56 & \# \\
\hline 0.60 & 52 & \# & 166 & \# & 45 & \# & 37 & 51 & \# & 61 & 54 & \# \\
\hline 0.65 & 52 & \# & 163 & \# & 42 & \# & 23 & 49 & \# & 56 & 52 & \# \\
\hline 0.70 & 52 & $\#$ & 159 & $\#$ & 40 & $\#$ & 10 & 46 & $\#$ & 51 & 50 & $\#$ \\
\hline 0.75 & 51 & $\#$ & 155 & $\#$ & 38 & $\#$ & 0 & 44 & $\#$ & 46 & 47 & $\#$ \\
\hline \multicolumn{13}{|c|}{ Optimum fertilizer P (kg/ha) } \\
\hline 0.15 & 27 & \# & 99 & $\#$ & 33 & $\#$ & 79 & 36 & \# & 52 & 37 & $\#$ \\
\hline 0.20 & 26 & $\#$ & 98 & \# & 32 & \# & 72 & 35 & \# & 49 & 36 & \# \\
\hline 0.25 & 26 & $\#$ & 96 & $\#$ & 31 & $\#$ & 65 & 34 & $\#$ & 47 & 35 & $\#$ \\
\hline 0.30 & 26 & \# & 94 & \# & 29 & $\#$ & 59 & 33 & \# & 45 & 34 & \# \\
\hline 0.35 & 26 & $\#$ & 92 & $\#$ & 28 & $\#$ & 52 & 32 & $\#$ & 42 & 32 & $\#$ \\
\hline 0.40 & 26 & $\#$ & 90 & $\#$ & 27 & $\#$ & 45 & 30 & $\#$ & 40 & 31 & $\#$ \\
\hline 0.45 & 26 & $\#$ & 88 & $\#$ & 26 & $\#$ & 39 & 29 & $\#$ & 38 & 30 & $\#$ \\
\hline 0.50 & 26 & $\#$ & 86 & $\#$ & 25 & $\#$ & 32 & 28 & $\#$ & 35 & 29 & $\#$ \\
\hline 0.55 & 26 & \# & 85 & $\#$ & 24 & \# & 25 & 27 & $\#$ & 33 & 28 & $\#$ \\
\hline 0.60 & 26 & \# & 83 & $\#$ & 22 & $\#$ & 18 & 26 & $\#$ & 30 & 27 & $\#$ \\
\hline 0.65 & 26 & \# & 81 & \# & 21 & $\#$ & 12 & 24 & \# & 28 & 26 & \# \\
\hline 0.70 & 26 & $\#$ & 79 & $\#$ & 20 & $\#$ & 5 & 23 & $\#$ & 26 & 25 & $\#$ \\
\hline 0.75 & 26 & \# & 77 & \# & 19 & \# & 0 & 22 & \# & 23 & 24 & \# \\
\hline
\end{tabular}

\# indicates calibration not possible due to non-diminishing response of a nutrient

WSI: Crop season water stress index

D2: SMW 30 (23-29 July)

D4: SMW 34 (21-26 August)

M2: Skip row with furrow
D1: SMW 28 (9-15 July)

D3: SMW 32 (6-12 August)

M1: Ridge \& Furrow

M3: Flat bed

\section{ACKNOWLEDGEMENTS}

The authors express their gratitude to the staff of the Cooperating Center of All India Coordinated Research Project for Dryland Agriculture located at Solapur, Maharastra, for providing the necessary infor- 
mation for the development of models and conclusions drawn in this paper.

\section{REFERENCES}

Doorenbos, J. and Kassam, A.H., 1979. Yield response to water. FAO Irrigation \& Drainage. Paper 33. FAO, Rome.

Draper, N.R. and Smith, 1973. Applied Regression Analysis. John Wiley and Sons Inc., New York.

Hanumantha Rao, C., Maruthi Sankar, G.R., Sanghi, N.K. and Girija, A. 1993. Quantification of rainfall effects on grain yield of sorghum genotypes in dryland alfisols. Journal of Indian Society of Agricultural Statistics 45(3): 341-349.

Maruthi Sankar, G.R., 1986. On screening of regression models for selection of optimal variable subsets. Journal of Indian Society of Agricultural Statistics 38(2): 161-168.

Maruthi Sankar, G.R. and Sonar, K.R., 1987. Optimizing fertilizer requirement using Linear Programming model with soil test crop response data. Indian Journal of Agricultural Sciences 57(8): 587-593.

Maruthi Sankar, G.R., Sonar, K.R. and Reddy, K.C.K., 1988. Pooling of experimental data for predicting fertilizer requirements of rabi sorghum for varying soil test values. Journal of Maharastra Agricultural Universities 13(1): 59-62.

Maruthi Sankar, G.R., 1992. Application of Statistical Model-Building and Optimization Techniques in Fertiliser Use Research. Chapter 28 in the book on Dryland Agriculture: State of Art of Research in India. pp. 653-671.

Maruthi Sankar, G.R., Vanaja, M. and Raghuram Reddy, P., 2001. Selection of superior genotypes of sunflower using regression analysis. Helia 24(34): 49-62.

Maruthi Sankar, G.R. and Vanaja, M., 2003. Crop growth prediction in sunflower using weather variables in a rainfed alfisol. Helia 26(39): 125-140.

Maruthi Sankar, G.R., Vanaja, M., Maruthi, V., Raghuram Reddy, P. and Narasimha Murthy, D., 2004. Selection of consistent plant traits for sunflower growth using principal component analysis. Helia 27(41): 113-122.

Victor, U.S., Mandal, U.K., Rao, K.V. and Vittal, K.P.R., 2003. Comparative evaluation of different soil water balance models in the estimation of root zone soil moisture. Journal of Agrometeorology 5(2): 1-14.

Vittal, K.P.R., Maruthi Sankar, G.R., Singh, H.P., Balaguravaiah, D., Padmalatha, Y. and Yellamanda Reddy, T., 2003. Modeling sustainability of crop yield on rainfed groundnut based on rainfall and land degradation. Indian Journal of Dryland Agriculture Research \& Development 18(1): 7-13.

\section{REQUERIMIENTOS PARA OPTIMIZAR LA FERTILIZACIÓN EN GIRASOL DE SECANO BASADOS EN ÍNDICES DE ESTRÉS HÍDRICO DE SUELOS VARIABLES EN VERTISOLES SEMIÁRIDOS DE INDIA}

\section{RESUMEN}

Se condujeron seis experimentos a campo cuyos tratamientos comprendían cuatro fechas de siembra (siembra durante diferentes semanas meteorológicas estándar: 28 (9-15 de julio), 30 (23-29 de julio), 32 (6-12 de agosto) y 34 (21-26 de agosto), tres métodos de conservación de humedad (camellón y surco, surco salteando una hilera y cama de siembra plana) y tres niveles de fertilizante NP (4-20, 50-25 y 60-30 kg/ha) durante la estación kharif de 1999 a 2004 en Solapur en vertisoles semiáridos. Se midieron los índices de estrés hídrico de suelo (MSI) para cada combinación de fecha de siembra (DOS) y método de conservación de suelo (MC) en cada estación sobre la base de lluvia diaria (RF), escurrimiento diario (RO) y estación de cultivo. 
Análisis de correlación indicaron una relación positiva entre el rendimiento de semilla y la lluvia en las cuatro DOS. La relación fue relativamente mayor para cama de siembra plana en la $1^{\mathrm{er}}$ DOS, camellón y surco en la $2^{\text {da }}$ DOS y para surco salteando una hilera en la $3^{\text {ra }}$ y $4^{\text {ta }}$ DOS. El rendimiento se relacionó negativamente con RO en la $1^{\mathrm{er}}$ DOS y positivamente en las otras 3 DOS. Esta relación fue mayor bajo el sistema de camellón y surco en la $1^{\text {er }}$ DOS (negativa) y $4^{\text {ta }}$ DOS (positiva) y bajo el sistema de cama de siembra plana en la $2^{\text {da }}$ y $3^{\text {er }}$ DOS. Se encontró una relación negativa entre MSI y rendimiento majo las 12 combinaciones de DOS y MC, indicando una mayor correlación bajo surco salteando una hilera en la $1^{\mathrm{er}}, 2^{\mathrm{da}}$ y $4^{\mathrm{ta}}$ DOS y con cama de siembra plana en la $3^{\mathrm{er}}$ DOS. La relación entre RF y RO fue positiva, mientras que MSI tuvo una relación negativa con RF y RO.

Se calibraron modelos de regresión del rendimiento de semilla con RF, $\mathrm{RO}$, SMI, fertilización con $\mathrm{N}$ y P e interacción MSI $\times$ fertilización. El rango de predecibilidad varió de 0,12 (camellón y surco en la $3^{\mathrm{er}} \mathrm{DOS}$ ) a 0,91 (cama de siembra plana en la $1^{\mathrm{er}}$ DOS). Un cálculo de las dosis óptimas de $\mathrm{N}$ y $\mathrm{P}$ al variar los niveles de MSI $(0,15$ a 0,75$)$ indicó que el método de camellón y surco es eficiente en la $1^{\mathrm{er}}$ DOS con un óptimo de N y P entre 51 y $53 \mathrm{~kg} / \mathrm{ha} \mathrm{y} 26$ a 27 $\mathrm{kg} / \mathrm{ha}$, respectivamente. El método de surco salteando una hilera fue eficiente con el cultivo sembrado en cualquiera de las otras DOS, con un óptimo de $\mathrm{N}$ entre 38 y $66 \mathrm{~kg} / \mathrm{ha}\left(2^{\text {da }}\right.$ DOS), 44 a $73 \mathrm{~kg} / \mathrm{ha}\left(3^{\text {ra }}\right.$ DOS) y 47 a $74 \mathrm{~kg} / \mathrm{ha}\left(4^{\text {ta }}\right.$ DOS). La aplicación óptima de P varió de 19 a $33 \mathrm{~kg} / \mathrm{ha}$ (2 ${ }^{\mathrm{da}}$ DOS), 22 a $36 \mathrm{~kg} /$ ha ( $3^{\text {ra }}$ DOS) y 24 a $37 \mathrm{~kg} / \mathrm{ha}\left(4^{\text {ta }} \mathrm{DOS}\right)$ para alcanzar la máxima productividad de girasol en vertisoles semiáridos.

\title{
APPORT OPTIMAL NÉCESSAIRE DE FERTILISANTS POUR LE TOURNESOL EN FONCTION DE LA VARIATION DE L'INDICE D'HUMIDITÉ DES SOLS DANS DES CONDITIONS SEMI-ARIDES (VERTISOLS) D'INDE
}

\author{
RÉSUMÉ
}

Six expériences sur le terrain ont été faites sur le tournesol au moyen des traitements suivants : quatre dates de semis (pendant différentes semaines météorologiques standard, c'est-à-dire 28 (9-15 juillet), 30 (23-29 juillet), 32 (6-12 août) et 34 (21-26 août); trois méthodes de conservation de l'humidité du sol (labour en billons, semis en sillon avec rangs d'espacement intermédiaires et semis en sol plat) et trois niveaux de fertilisants NP (40-20, 50-25 et 60-30 $\mathrm{kg} / \mathrm{ha}$ ) pendant les saisons de kharif de 1999 ñ 2004 à Solapur dans des conditions semi-arides (vertisols). Les indices de stress dû au degré d'humidité du sol (MSI) ont été mesurés sur la base des précipitations quotidiennes (RF), de la perte quotidienne d'eau ( $\mathrm{RO}$ ) et de la saison de la récolte pour toutes les dates de semis (DOS) combinées à la méthode de conservation de l'humidité (MC) à chaque saison.

L'analyse corrélative a montré une corrélation positive entre le rendement et les précipitations pour les quatre dates de semis. La relation a été relativement plus élevée pour le semis en sol plat pour la première date de semis, pour le labour en billons pour la deuxième date et pour le semis en sillon avec rangs d'espacement intermédiaires pour les troisième et quatrième dates. On a constaté une relation négative entre le rendement et la perte quotidienne d'eau pour la première date de semis, mais une relation positive pour les trois autres 
dates de semis. La relation était élevée pour le labour en billons pour la première date de semis (négative) et pour la quatrième date (positive), et pour le semis en sol plat pour la deuxième et la troisième date. Une relation négative de l'indice d'humidité du sol (MSI) et du rendement a été constatée pour les 12 dates de semis combinées è l'humidité du sol avec une relation élevée pour le semis en sillon avec rangs d'espacement intermédiaires pour la première, la deuxième et la quatrième date de semis et pour le semis en sol plat è la troisième date de semis. La relation entre les précipitations quotidiennes et la perte quotidienne d'eau a été positive tandis que l'indice d'humidité du sol a été en corrélation négative autant pour les précipitations quotidiennes que pour la perte quotidienne d'eau.

Les modèles de régression du rendement en graines en rapport avec les précipitations quotidiennes, la perte quotidienne d'eau, l'indice d'humidité du sol, les fertilisants $\mathrm{N}$ et $\mathrm{P}$ ainsi qu'en rapport è l'interaction fertilisant $\times$ indice d'humidité du sol ont été calculés. Les valeurs prévues s'échelonnaient entre 0,12 (pour le labour en billons pour la troisième date de semis) à 0,91 (pour le semis en sol plat pour la première date de semis). Un barème des doses $\mathrm{N}$ et $\mathrm{P}$ optimales à différents niveaux de stress dè au degré d'humidité du sol $(0,15$ à 0,75 ) a montré que la méthode de labour en billons est efficace pour la première date de semis avec des doses $\mathrm{N}$ et $\mathrm{P}$ optimales qui s'échelonnent de 51 à $53 \mathrm{~kg} / \mathrm{ha}(\mathrm{N})$ et de 26 à $27 \mathrm{~kg} / \mathrm{ha}(\mathrm{P})$ respectivement. La méthode de semis en sillon avec rangs d'espacement intermédiaires a été efficace pour les autres dates de semis avec des valeurs $\mathrm{N}$ optimales qui s'échelonnaient de 38 à $66 \mathrm{~kg} /$ ha (deuxième date de semis), de 44 à $73 \mathrm{~kg} / \mathrm{ha}$ (troisième date de semis) et de 47 à $74 \mathrm{~kg} /$ ha (quatrième date de semis). La valeur optimale $\mathrm{P}$ s'échelonnait de 19 à $33 \mathrm{~kg} / \mathrm{ha}$ (deuxième date de semis), de 22 à $36 \mathrm{~kg} / \mathrm{ha}$ (troisième date de semis) et de 24 à $37 \mathrm{~kg} / \mathrm{ha}$ (quatrième date de semis) pour l'obtention d'une productivité maximale du tournesol dans des conditions semi-arides (vertisols). 
